\title{
Republic of Moldova: Diaspora and Diaspora Policy
}

\author{
Valeriu Mosneaga ${ }^{1}$, \\ Institute of Social Sciences, UCM in Trnava, Slovakia
}

Republic of Moldova: Diaspora and Diaspora policy. In this article the Moldovan Diaspora and Moldova's policy regarding Diasporas phenomena are researched. The historical and the contemporary contexts of formation of Moldovan Diasporas are revealed. The roles of Moldovan citizens' labor migration as well as the formation of Moldovan communities and Diasporas abroad are analyzed. The main directions of Moldova's Diaspora policy are shown: visa free regime and readmission; mobility and circular migration; juridical and social protection of Moldovan migrants abroad; the return and reintegration of Moldovan labor migrants into their homeland's society. The role of state bodies in the development and implementation of migration policies on a national level is analyzed; the institutional changes and role of the Bureau for the Relations with Diaspora in the coordination of Moldovan state structures' activity towards working with the Moldovan Diaspora is demonstrated. The role of non-state actors (migrant associations, Diaspora congresses, the church, trade unions, and other) in maintaining of language, culture, traditions, Moldovan identity, in the social and economical development, and Moldova's cooperation with the accepting country are revealed. The state's activity in protecting and respecting the political, socioeconomical, and cultural rights of Moldovan emigrants is characterized.

Key words: Moldovan Diaspora, Diaspora policy, visa free regime and readmission, mobility and circular migration, returning of labor migrants, ethnocultural associations, rights of Moldovan emigrants.

Moldavská republika: Diaspóra a politika diaspóry. $\vee$ tomto článku sa skúma moldavská diaspóra a moldavská politika týkajúca sa fenoménu diaspóry. Odhalujú sa historické a súčasné kontexty formovania moldavskej diaspóry a analyzujú sa úlohy pracovnej migrácie moldavských občanov ako aj vznik moldavských komunít a diaspór $v$ zahraničí. Ukazujú sa hlavné smery politiky moldavskej diaspóry: bezvízový režim a znovuprijatie; mobilita a kruhová migrácia; právna a sociálna ochrana moldavských migrantov v zahraničí; návrat a opätovná integrácia moldavských pracovných migrantov do spoločnosti vo vlasti. Analyzuje sa úloha štátnych orgánov vo vývoji a implementácii migračnej politiky na národnej úrovni; demonštrujú sa inštitucionálne zmeny a úloha Úradu pre vzt’ahy s diaspórou v koordinácii činnosti moldavských štátnych štruktúr $\mathrm{k}$ práci $\mathrm{s}$ moldavskou diaspórou. Úloha neštátnych aktérov (migračné združenia, kongresy o diaspóre, cirkev, odbory a ostatné) v udržiavaní jazyka, kultúry a tradícií, moldavskej identity v sociálnom a hospodárskom vývoji, a odhal'uje sa moldavská spolupráca s prijímacou krajinou. Charakterizuje sa činnost' štátu v ochrane a rešpektovaní politických, sociálno-ekonomických a kultúrnych právach moldavských emigrantov.

${ }^{1}$ Address: Prof. Valeriu Mosneaga, Mateevici 60, Chisinau, M-2009, Republic of Moldova. E-mail: mosneaga@hotmail.com

Slovak Journal of Political Sciences, Volume 14, 2014, No. 2

DOI: 10.2478/sjps-2014-0007 
Klúčové slová: moldavská diaspóra, politika diaspóry, bezvízový režim a znovuprijatie, mobilita a kruhová migrácia, návrat pracovných migrantov, etno-kultúrne združenia, práva moldavských emigrantov

\section{Introduction}

Under deep social and economic crisis since the Republic of Moldova independence years, according to official statistics more than 210,000 people had left abroad for permanent residence (10\% left to the EU, $9 \%$ of which are in Germany only). At the same time, with the second half of the 90's of the XX century begins a massive process of international labor migration. Currently in the process of temporary labor migration, more than 700,000 people are involved, accounting about $50 \%$ of the economically active population of the country (35\% of which are in the EU) (Moldova, 2011: p.60). On the one hand, that leads to the formation of the Moldovan communities abroad and Diaspora in many countries around the world. On the other hand, it exacerbates the problems of demographic security, insurance of national labor markets that are threats to the democratic political and sustainable socio-economic development of the country.

Trying to minimize the negative effects and risks of mass emigration, the Moldovan government begins to pursue a policy of emigration and Diaspora. Today the Moldovan politics is deepening in the context of cooperation with the European Union in the framework of the Eastern Partnership and the immediate neighborhood with the EU.

Initially, the policy on forming Moldovan Diaspora has focused on ensuring cultural ties with its homeland, and later on the socio-economic and political relations. This was conditioned by the increasing collaboration with states receiving Moldovan labor migrants as well as the growing interest of Moldovan political leaders to get support during elections from the migrant workers.

We note that since the period of independence, no government, no political party of the country acted against democratic principles of freedom on leaving and entering the country, closing the boundaries and artificial restraints of emigration process. At the same time political parties do not pay significant attention to the problems of migration: they mainly focus on the approval of the problems, determine their causes and trends, but not on the migration policy. The attitude to Diaspora is focused mainly on the electoral purposes or its leveraging investment for the economic development of the country (Oprunenco, 2012; Makaryan, 2013). 


\section{Researching the Diaspora problematic}

The research in the Diaspora domain is new, relevant, and not yet profound. As we have already mentioned, it is mostly due to the absence, underdevelopment of the object of study itself.

The subject was first taken into consideration by the Moldovan governmental structures in 2000, when was issued a presidential decree regarding Moldovan citizens living abroad (Presidential, 2000).

The first attempt to analyze the process of Moldovan Diaspora formation was made by A.Margarint and A.Morozan. They have pointed out the importance of labor migration in the appearance of Moldovan citizens abroad, as well as the activity of Moldovan authorities in supporting them (Morozan, 2006). A bit earlier, also in 2006, P.Cabacenco characterized the role of the internet in the development of transnational migrant networks and Diasporas (Cabacenco, 2006).

We should also mention the work of R.Schwartz (Israel), who, during the International Migration Organization project, in 2007, researched the formation of Moldovan Diasporas abroad (both weak and strong aspects), taking Israel, Italy, and Russia as an example. Knowing how uncertain contemporary Moldovan Diasporas are, he unified the whole Moldovan society abroad with the Diaspora, considering that the current state of development doesn't permit the use of conventional methods of analyses (Schwartz, 2007).

Using R.Schwartz's methodology, V.Mosneaga and R.Rusu have analyzed the currently-existing definitions of Diaspora, attempted to do a complex study of its formation, and have discovered the main directions of the Moldovan migration policy regarding the support given to Moldovan societies and diasporas abroad (Mosneaga, 2008).

A book written by V.Mosneaga, V.Moraru, G.Rusnac and V.Turcan was published in 2011. Its main topic is Moldovan labor migration to Italy. It contains a complex study of Moldovan societies in Italy, made by both Moldovan and Italian scientists, based on interviews with labor-migrants and experts; Moldovan and Italian statistics. Big attention was paid to the aspects of Moldovan citizens integration into Italian society (knowledge of language, preoccupation, education, residential status, citizenship, social interaction with both the accepting country, and the motherland - the Republic of Moldova). An indisputable advantage of this particular work was that the texts of the interviews were included into the annex (Mosneaga, 2011).

In 2012 came out a book written by V. Moraru, V. Mosneaga, and G. Rusnac, dedicated to a complex analyzes of migration processes and Moldova's migration policies for the period of 1990-2011. Migration policy in the domain of diasporas plays a big role in this book. The chapter regarding the 
return of labor migrants from the EU back to their motherland during the world financial crisis is worthy to mention. This problem is viewed through the prism of interviews taken with Moldovan citizens abroad (Moraru, 2012).

We should also mention the V.Mosneaga's article regarding the integration of Moldovan labor-migrants into the EU countries. Using the MIPEX methodology on politics of migrant integration, and sociological analyses, the author studies Moldovan societies in EU countries, and the different aspects of integration into their societies (language; the access to the labor-market and mobility, family reunion, access to education, political activity, long-term stay status, citizenship, social interaction antidiscrimination. The article brings about an index of integration of migration policies in different EU countries (Mosneaga, 2012b).

The researches made within the CARIM-East (Eastern Neighborhood) project of the Center of Migration Policy of the European University Institute (Firenze, Italy) in 2011-2013 are also of great importance. During these projects, were studied the different aspects of Moldovan migration and Diaspora policies, regarding readmission, return, and reintegration of labormigrants in Moldova, (Brunarska, 2013; Ciumas, 2012; Ganta, 2012; Mosneaga, 2012a: Mosneaga, 2012c; Stratan, 2013).

In 2013 two more books were published. These were prepared during the MOM project of mapping the Moldovan Diaspora entitled "The Mapping the Moldovan Diaspora abroad". As a result of sociological research, a big empirical database of abroad Moldovan societies was gathered; a comparative analysis of the situation of Moldovans in Russia and a number of EU states is made. However, the integration aspects of Moldovan citizens in these countries did not get proper exposition (Cheianu-Andrei, 2013; Mukomel, 2013).

At the same time, it should be mentioned that due to the underdevelopment of the phenomena of Moldovan Diaspora, the research of Moldovan Diaspora policy specifics in different states is not made. Without discussing the differences of Moldovan societies and diasporas abroad, Moldovan scientists have concluded that "the Moldovan diasporas in many EU countries, even the ones that have a big number of Moldovan societies, are only forming, but when working with these young diasporas, we must treat them as if they're fully formed and functional" (Moraru, 2012: 183), and Moldova's migration policies must also keep that in mind.

\section{Historical context}

Unlike the other countries within the post-Soviet space, Moldova has never met with the Diaspora phenomena before. This is explained by the specific historical and cultural development of the Moldovan state. 
- Moldovans that migrated to Romania during the pre-WWII and WWII periods (1918 - 1944), have integrated themselves into Romanian society, leaving their former identity behind. Since the post-war Romania-USSR relationships were strained, Soviet-Moldovan authorities were not interested in staying in touch with Romania and its citizens, including the ones that left previously, as well as their descendents.

- Moldovan emigrants (born in Moldova, Bessarabia, Transnistria), of the preSoviet and Soviet periods, have assimilated into the accepting country's societies (Romania, the USA, Israel, Germany). One rare exception was the Society of Bessarabian Germans (in Germany), which was founded by Germans, who were forcedly exiled by Soviet authorities, from Bessarabia, in 1940 (in accordance to the Ribbentrop-Molotov pact's secret protocols). However their ties to Soviet Moldova were almost inexistent.

- Moldovan mass-migrations within the single-state USSR were not followed by the forming of Diasporas in the other regions of the USSR. Moldovans born in Ukrainian (Odessa, Chernivtsy, and Transcarpathia) and Russian (Kuban, Far Eastern, Tyumen, and Transbaikalia) regions did not consider themselves a Diaspora (Mosneaga, 2013).

\section{Contemporary context}

Moldovan societies began forming abroad once Moldova proclaimed its independence (in 1991), and its citizens got the right to travel to other countries (emigration, marriage, family reunions, studies, etc.). During the second part of the 1990's, the process received a mass-character with the development of Moldovan labor-migration to Russia, EU-states, Israel. The main goal of the newly-formed Moldovan NGO's, migrants' societies, students' fraternity, abroad is preservation of the national, cultural, religious and linguistic identity of Moldovans and Moldovan citizens abroad; as well as the establishment and strengthening the relationship between them.

For a significant time, the aspect of formation of Moldovan communities abroad could not be linked to the development of the Moldovan Diaspora. The main reasons for this were as follows (Mosneaga, 2013):

Firstly, the results of sociological research have yielded a high repatriation sentiment among Moldovan labor-migrants: more than $90 \%$ into Russia - as the epicenter of the CIS (the regional post-Soviet migration system); around 80\% into EU-states (the second most attractive regional migration system). Moldovan citizens - the ones participating in labor-migration - wished to return home, and saw themselves, and their future only in Moldova.

This is explained by the fact that Moldovan citizens left home to find work, not to settle down permanently. Accordingly, life plans, strategies, and orientations included - as the final goal - the home return, after a certain period 
abroad (a year, two, five, etc.). The realization of this goal was based on material and financial aspects (aiding their family, make money to buy a house / apartment / car, start a business, educate their children, save money for "a rainy day" and old age, etc.). With this in mind, the labor-migrant would base their return on their own strength, and the activity undertaken, to reach the immediate goals.

Secondly, empirical sociological studies were made within the borders of the Republic of Moldova. If at first these studies were accurate, later methodological omissions of the approach were found, as the approach favored the study of temporary (mostly seasonal) labor-migrations. However, reality has shown (and polls have documented) that a bigger part of labor-migrants would not return home, staying in the accepting countries for a variety of reasons, thus becoming these "labor migrants".

Thirdly, Diaspora-formation processes abroad were hidden from researchers, as the integration of Moldovan migrants into the new societies was unobvious. This was due to a high number of unregulated / illegal statuses of Moldovan labor-migrants within the accepting countries. As a result, the influence of integration mechanisms, proposed by EU-states (citizenship, access to education, labor-market, labor-mobility, political activity, long-term legal status, acquisition of property, etc.) was relatively weak.

Lastly, there is a variety of nuances appearing in Moldovan labor-migration processes. Since the second part of the first decade of XXI century, arrival (tourist visas got replaced by labor contracts), and stay (a regulated status of life and labor-activity) channels in the EU have changed. The possibilities of receiving a long-term status and citizenship have developed. Many labormigrants, due to the length of their stay, have started claiming the accepting country's citizenship (it is mostly prominent in Portugal).

Under these circumstances, labor-migrants are forced to make corrections of their return-plans; Repatriation is postponed to an unknown date. This prolongation is usually explained by the migrants' children study in the accepting-country's educational institutions, the possession of housing/ transportation credits by the migrants (as well as the necessity to pay for them).

Material and financial reasons for returning home are replaced with the societal ones. These are based on the effectiveness of the democratic political system's functionality, as well as the market-economy. As such, the labormigrant's wish to return is not only determined by their own possibilities, but by the possibilities/actions of the motherland's authorities towards the realization of the migrant's goal as well. With this, the result itself evolutionized, becoming more complex, under the influence of the accepting country's policies and realities towards legal migration. Each person adds 
something new to the overall return motivation: Moldova must approach to their vision of attractiveness; it must become comparable to the EU countries.

Changes take place within researches. The study of Moldovan migration moves out of the "national box". Researches are made both in Moldova, and in the accepting countries. The parallel study of Moldovan labor-migrants, made by both Moldovan, and foreign scientists, was very productive. It has shown that "a contingent of two different labor-migrant groups was studied" (Mukomel, 2013). Using the "comet" principle, we have categorized the groups into: the "comet's core" (Moldovan labor-migrants interviewed in the accepting countries - mostly in forming diasporas), and the "comet's tail" (Moldovan citizens, interviewed at home - mostly circular migrants, "the seasonals").

\section{State policy in relation with Diaspora}

Based on modern specifics of the Moldovan Diaspora, under the policy in relation with Diaspora we mean any state or non-governmental activity that promotes labor migration, supports the return of migrants to their home, focusing on its citizens and their descendants abroad, and promotes the conservation of relations between the country and Diaspora.

\section{Policy at the national level}

Visa free regime and readmission. The Republic of Moldova undertakes real steps to ensure the democratic rights and freedoms for its citizens. One of the rights referred to the right to freedom of movement, the right to leave and return to the country. In 1994, the right to leave and return to the country got a constitutional provision (the Constitution of the Republic of Moldova, Article 27), which was then developed under the law on "Leaving and entering the Republic of Moldova" (1994), the law on "Identity documents of the national passport system" (1994).

Meanwhile, there is no fixed term for leaving the country anymore. The only condition for the freedom to leave (the law on "Leaving and entering the Republic of Moldova") refers to presence of relevant documents (passport, travel documents ${ }^{2}$ ), as well as certain restrictions on exit (art. 8) related to national security.

\footnotetext{
${ }^{2}$ According to the law adopted in 1994, some categories of citizens (children, students) will have to present travel documents - which permit them to leave country alongside their passport. For children, it's the parents' permission to go abroad, certified by the notary. When both parents escort the child, there is no need for such a document. In cases when only one parent does (or if the parents are divorced), it is impossible to take the child abroad without such a document. If the child is escorted by
} 
The law on "Labor Migration" (2008) recognizes the right to freedom of movement, and introduces certain restrictions (Article 23) of Moldovan citizens travelling abroad. These restrictions are associated with both the decisions of the Court of Criminal Responsibility, and with the property and family commitments, the custody of children of migrant workers, etc.

We note that in July 2013 was made a decision of payment (from January 2014), regarding a token amount, fixed to those who go abroad for purposes of tourism. We believe that in future we should expect some taxes also for those who go abroad for work.

Moldova seeks to get free visa regime for its citizens with the EU, because it is understood that the current visa regime has some obstacles on returning the migrants to their home. If within Community Independent States area Moldovan labor migrants enjoy visa-free regime (Bishkek Agreement (1992)), then concerning the EU countries, it is pursuing the policy aimed at achieving it.

Since 2006, the Republic of Moldova has followed the goal of European political and economic integration and introduced the unilateral visa regime for all EU countries, Switzerland, Norway, the USA, Canada, Israel, and Japan.

The EU policy is to offer visa facilitation agreement, which is linked with signing the readmission agreement. At the end of 2007 these documents were signed. The agreement entered into force for Moldovan citizens on January 1, 2008.

Mobility and circular migration. Despite the fact that circular migration is not discussed as a separate priority in the National Strategy on Migration and Asylum for 2011 - 2020, today the Moldovan authorities undertake measures to consolidate the circular nature of labor migration. In respect of circular labor migration there is no debate in the Moldovan society. All political and social actors in Moldova understand the detrimental effects of mass migration on sustainable socio-economic development of the country (Oprunenco, 2012; Makaryan, 2013).

In June 2008, at its initiative the Republic of Moldova was chosen as the country (along with Cabo Verde) to be a partner of the Mobility Partnership. In this framework several projects on circular migration were implemented (Vremis, 2013: 206, 215; Moraru, 2012: 82-83).

The circular migration is seen as a way to strengthen the capacity of Moldova in the field of labor migration and irregular migration. It is the prospect "to hold" Moldovan citizens in the country, to prevent the negative effects of emigration and the way to encourage Diaspora investment in the

a third person, a letter of attorney is necessary, alongside the parents' permission. Both are to be certified by the notary. 
economy of Moldova. The basic principles of this policy are set out in the "National Strategy on Migration and Asylum" (2011-2020), characterized by fundamentally new approaches on migration policy, a complex combination of goals, targets and mechanisms to achieve them. Among the objectives there can be emphasized: - to promote the models of returning migration, with strengthening its positive impact on the migrant of sending and receiving societies; - warning unregulated migrations regarding employment on improving the measures taken at all stages of the migration control over the activities of economic agents that act as intermediaries between migrants and the foreign employers; - the transfer of the positive consequences of returning migration (transfer of knowledge / skills, diversification of opportunities and facilitation of investment of remittances of their own business in the real sector of the economy, stimulating the creation of joint companies with the participation of workers and employers of the host countries); - strengthening the capacity of the diplomatic missions and consular offices abroad to provide services in the field of social and economic rights of migrant workers, for dialogue with the host society and the Moldovan Diaspora to support the return of migrant workers at home, etc.; - the consolidation of relations with Diaspora and facilitation of transfer of "Social remittances" - democratic, economic, cultural, and gender relations, practices, organization and functioning of the community, contributing to the sustainable development of the country (Decision, 2011).

Generally, the implementation of this policy has not still given the desired effect, because of the global financial and economic crisis $(2008-2010)$ that affected the decrease of interest of the European Union countries.

Returning of labor migrants. In 2008, the Government has developed and implemented an Action Plan, encouraging the Moldovan labor migrants to "return home", for their reintegration. The plan refers to different activities on informing workers about job opportunities at home, returning procedures, opening their own business, increasing opportunities for youth employment, social protection, etc. Meanwhile the effect of such actions is not great, mainly because of socio-economic situation in the country.

The Moldovan authorities conduct the program "PARE 1+1" for the period 2010 - 2014, that is a state program which supports development of small and medium business (2009 - 2011), (Pilot, 2010) ${ }^{3}$, The National Program for Economic Empowerment of Youth (PNAET), which provides entrepreneurial

\footnotetext{
${ }^{3}$ The point of the program is to stimulate investments by attracting the migrants' capital. The migrant and the state both invest in the migrant's business, in accordance with the 1+1 dollar (euro) principle.
} 
training skills as well as financial assistance for business start-ups. In addition, the implemented measures are focused on recognition of skills and qualifications (the National Concept and Recognition of Non-formal / Formal Training, approved in November 2011); the activities organized by local labor market in the context of EU - Moldova Mobility Partnership, etc. Although the Action Plan on returning the Moldovan labor migrants from abroad (2008) has expired, the return and reintegration of Moldovan migrants remains an important goal, determining a National Strategy on Migration and Asylum (2011 - 2020) and the Action Plan for 2011 - 2015.

Together with international organizations are implemented the large number of projects in this area: "Strengthening Moldova's capacity to manage labor and return migration", "Effective Governance of Labor Migration and its Skills Dimensions in Moldova", "Supporting the implementation of the migration and development component of the EU-Moldova Mobility Partnership", "Development of the Vocational Training and Education System", etc.

We emphasize that it is not simple at all for the migrants after their return. They face many reintegration problems. An important issue regarding reintegration refers to problems of employment and professional adaptation (salary, place of work, the recognition of qualifications). Moldova undertakes some efforts for recognizing the skills and abilities, developed in practice and supported with relevant official documents. Undoubtedly, the solving of the problems of employment may lay in business development, small business of returned people, whose finances and energy could improve the situation in the national labor market. However, there are also problems in this context. The implementation of the program "PARE $1+1$ " broke down due to the lack of government finances: the project actually turned into a "3+1" that does not contribute to confidence strengthening to the state. Under these conditions, migrants often have no other choice than to emigrate again.

Diaspora. In Moldova, there is no conceptual document/strategic plan in the field of Diaspora, but there is sufficiently developed legal framework. Through these documents were adopted Regulation of Coordinating Council for the Diaspora Support (2005), Regulation of Financial Support for Preservation of the National Cultural Identity of the Diaspora (2007), Program for Diaspora Support (2006), the National Action Plan for Diaspora Support (2008), the National Action Plan to promote the Return of Moldovan Labor Migrants (2008). A particular importance refers to the Disposition of the Government (2011), where there were formulated decisions on creation the Agency for the Diaspora affairs, on developing the Action Plan for 2011-2014 to support the Moldovan Diaspora. This plan should be a supplement to the Action Plan on the implementation of the National Strategy on Migration and Asylum (2011-2020). 
It should be noted that, despite the existence of serious contradictions between the political forces of Moldova on the ways of social development of the country, the Moldovan policy in relation to Diaspora is characterized by the sequence, being carried out in a number of directions:

- work with the Moldovan Diaspora, ethnic and cultural communities abroad. This process has become more intense since the first half of the 2000s. In order to strengthen ties of the Diaspora, since 2004 the Moldovan Authorities have been organizing (with an interval of 1 every 2 years) congresses of the Moldovan Diaspora, which serve to establish contacts, cooperation not only between Moldova and the Diaspora, but also within the Diaspora both within the country and between different countries. For the first time honouring the Moldovan expatriates with awards on ethno-cultural communities abroad (Diaspora) were held at the IV Congress of the Moldovan Diaspora (2010). Later it was organized in the period between the congresses, in particular, before the parliamentary (2011) elections.

Table. The dynamics of the participation of representatives of ethnocultural associations within the congresses of the Moldovan Diaspora (2004-2012)

\begin{tabular}{|c|c|c|}
\hline Year & The number of countries & The number of representatives \\
\hline 2004 & 12 & 120 \\
\hline 2006 & 22 & 170 \\
\hline 2008 & 20 & 220 \\
\hline 2010 & 31 & 250 \\
\hline 2012 & 22 & 100 \\
\hline
\end{tabular}

Source: http://diaspora.md/index.php?pag=news\&opa=view\&id=123\&tip=congrese $\&$ start=\&l=\$ $\mathrm{http}: / /$ diaspora.md/index.php?pag=news\&tip=congrese $\& \mathrm{l}=$

Also the preservation of national cultural identity plays an important role and the State in this respect contributes with the financial support. Since 2005, a special body (Coordinating Council) on the Diaspora was created. Since 2011, its members include representatives of the Moldovan Diaspora, who are elected by the Congress.

Thanks to the representatives of the Moldovan Diaspora (the Decision of the V-th Congress of Moldovan Diaspora, October 2012) was formed the Bureau for Relations with Diaspora ${ }^{4}$. The emerging Moldovan Diaspora is seen as an

${ }^{4}$ By the way, the Diaspora called for the creation of the Ministry of Migration and Diaspora 
important instrument for the development of mutual beneficial relations with other countries.

In August 2013was launched a program for children of Diaspora "Dor": it will cover children aged between 14 and 16, originally from Moldova, who live outside the country. Participants will be involved in a number of activities whose purpose is to familiarize with the customs, language and culture of their country of origin. The program is organized by the Bureau of Relations with Diaspora in partnership with the International Organization for Migration (Victor, 2013).

Since 2009 it has been conducting an active work and engaging Moldovan Diaspora in political life of the country. This has affected the increasing political role and electoral activity of the Diaspora in the parliamentary elections (2010). As a result of the conducted work among Moldovan citizens the number of Moldovans, who voted abroad has significantly increased. Since 2011 has been actively carried out the course of engaging the Diaspora in the economic development of the country.

- the work with the Moldovan scientific Diaspora. Since 2010, there are widely used projects (2010 - „Connecting Moldovan scientific Diaspora in the process of economic and scientific development of the Republic of Moldova", Moldovan Academia of Science in collaboration with the Federal Polytechnic School from Lausanne (EPFL); 2011 - 2012 - "Attracting Moldovan scientific Diaspora for the sustainable development of the country" Moldovan Academia of Science in collaboration with International Organization for Migration) to attract scientists, natives of Moldova for the development of scientific and technological capacities (Moraru, 2012: 92-93).

The dialogue with the Diaspora seems to become the fundamental aspect on which programs of remittances investments, both permanent and temporary involvement of migrants, their socio-economic reintegration at home are developed. Currently, an emphasis is made on the protection of Moldovan citizens abroad, the preservation of cultural identity and promotion of migrants returning home. It should be noted the Action Plan on support of migrants of the Republic of Moldova residing abroad (Moldovan Diaspora) for the period 2006 - 2009, the National Action Plan for 2008 on protection of citizens of the Republic of Moldova abroad, the Action Plan for national, cultural and social support for the Moldovan Diaspora for the period 2012 - 2014.

Governmental bodies. The regulation on immigration issues falls under the responsibility of several government agencies in the Republic of Moldova. The Ministry of the Internal Affairs (Bureau of Migration and Asylum) is engaged in the development of conceptual and strategic approaches and policies on migration and Diaspora; (border police) records the output of the country / entry into the country of Moldovan labor migrants going abroad to work, 
certifies the compliance and legality of travel documents. They are also concerned with the readmission of Moldovan citizens, third country nationals and stateless persons, included in the EU from the territory of the Republic of Moldova, etc. The Ministry of Information Technology (represented by state enterprise "Register") prepares and issues passports to Moldovan citizens, registers and monitors in the national database data. The Ministry of Economy develops policies on the labor market and employment of Moldovan citizens, provides economic aspects of cooperation with Diaspora (investments, etc.). The Ministry of Labor, Social Protection and Family develops agreements with foreign countries, businesses in the employment of migrant workers, their legal and social protection abroad. The Ministry of Health has tested the health of migrant workers. Licensing Chamber holds registration (licensing) and audit of Moldovan firms engaged in employment and shipment of Moldovan citizens who work abroad, as well as travel companies, which often "gain money" sending illegal migrants under the guise of tourists. The Ministry of Foreign Affairs and European Integration is cooperating with the Moldovan communities abroad, gathering the necessary information on foreign partners, provides consular and diplomatic protection of Moldovan citizens living and working abroad, employing readmission of the EU from third countries. Information and Security Service is collecting and verifying information on foreign partners to agreements on sending work abroad of Moldovan citizens. National Bureau of Interethnic Relations carries cultural cooperation with the Moldovan Diaspora and communities abroad.

Under the structure of the State Chancellery it was the Bureau on Relations with Diaspora (November 2012) which was designed to co-ordinate "the process of implementation of the state policy in the sphere of relations with Diaspora, to contribute to the preservation and confirmation of the ethnic, cultural and linguistic identity of Moldovans living abroad, and the development of human and material potential of Diaspora" (Decision, 2009), the activity of cultural, educational, economic and social order, undertaken by various ministries and other central authorities to support and cooperate with the representatives of Diaspora (leaders of Moldovan ethnical and cultural associations).

In December 2012, the Bureau for Relations with Diaspora was staffed, on competitive basis. Since February-March 2013 this structure is fully operational. The bureau has good cooperation with international organizations, and the Moldovan Diaspora. The Bureau for Relations with Diaspora held a large number of activities within the country and abroad; has become visible to the Moldovan authorities and the population, as well as the international public opinion (Activity, 2013). The Bureau for Relations with Diaspora is 
overarching institution with a coordination role over the other national governmental bodies dealing with Moldovan Diaspora.

There is a preparing a law on Diaspora, the work regulations of the Bureau on Relations with Diaspora in line with the government Action Plan on Diaspora for $2012-2014$. Today it is addressing the issue of competences and interactions of the Bureau on Relations with Diaspora in the development of public policy in the field of cooperation with Diaspora, the working out changes in regulations of other agencies. So, for the deputy ministers of the ministries that have relevant connection with migration, are planned extending functions, including also the coordination of activities with Diaspora.

\section{Current policies at the local/regional level}

Today there is no policy on the regional or local level. The Bureau on Relations with Diaspora strives to develop and propose such a policy in the context of migration and development within the UN program "Nexus". In June 2013 in Orheiul Vechi (Orhei District) was held a training seminar with representatives of the local administration authorities from several districts of the country, where was found that the weakness of the involvement of local authorities in carrying out immigration policy is largely affected by financial difficulties of local authorities. Interaction and cooperation between them has mainly an interpersonal character, as there is no mechanism of local authorities' cooperation in solving the problems of "migration and development".

\section{Engaging non state actors}

Ethno-cultural associations of Moldovan emigrants in foreign countries play a significant role in establishing relations between the Diaspora and Moldova. In 2013, in the Bureau of Interethnic Relations were registered 154 associations from more than 30 countries (118 associations from $18 \mathrm{EU}$ countries).

It should be noted that the Moldovan Diaspora collaborates with the Moldovan diplomatic missions abroad (since 2005), organized during celebrating the holiday dates. These are national and traditional holidays in Moldova, historical dates on the development of Moldovan state ${ }^{5}$. Such activities related to the promotion of culture, with the support of the embassies

${ }^{5}$ On the days of Moldovan national, or cultural, holidays; for example: Independence Day $-27^{\text {th }}$ of August, Our Language (Limba Noastra) day $-30^{\text {th }}$ of August, Spring day (Martisor) $-1^{\text {st }}$ of March, National Wine day $-14^{\text {th }}$ of October, Orthodox Christmas $7-8^{\text {th }}$ of January, etc. Celebrations of Moldovan national and cultural holidays are organized by the diplomatic missions and the Diasporas' ethno-cultural organizations. They take place both inside the diplomatic missions, and in the hosting country's territory. 
of Moldova, are the most visible activities abroad, and a part of policy creates the positive image of Moldova abroad. Thus, the Diaspora activities are limited to the organization of ethno-cultural activities, provision of the information services, meetings, organizing days of Moldovan culture and holidays. However, it is prematurely to speak about bigger projects and program activities involving the significant portion of emigrants from Moldova.

Migrant Associations often have formal character which are not known to the main public of migrants, the decision making process is not transparent. For the moment this situation is more common: there are organizations designed to work with the state, city authorities of the country for migrants, and there are those focused on working with the embassy of their states. However there is the increasing tendency to focus to work in the Diaspora (Italy, UK, and Portugal) ${ }^{6}$, etc.

There are cases when migrant organizations abroad seek to consolidate the Moldovan Diaspora, conducting congresses in the host country. Regarding that, we note Portugal, where the Moldovan Cultural Centre held the Congress of Moldovans in Portugal (2008), which was attended by 650 people. The most often organized congresses in the host country, with own forces of the Diaspora, are limited because of weak financial capacities.

The practice has shown that there are the same goals between the Moldovan Diaspora, ethno-cultural associations ${ }^{7}$ and the Republic of Moldova; there is no conflict among them. There are different objectives of the associations, covering the entire spectrum of human activities. However, engaging investments, providing services in this area have not been the major and top priorities yet. The associations of migrants are quite active, especially in dealing with philanthropic goals at the local level of migrant settlements. Their activities are often organized without involvement of the Moldovan authorities. If the activity is coordinated, it does not get much publicity. Basically, it is reflected at the local level, on the websites of the migrants' organizations. Organizations of migrants often seek to distance themselves from the government agencies because they do not want to be "cash cows" of the government, to be used in the party goals of power or opposition.

${ }^{6}$ These countries were mentioned specifically as the Moldovan ethno-cultural organizations, from those countries, proposed the initiative to Moldovan associations in other countries. Moldovan associations have addressed Moldovan migrants to support Moldova's representative on the Eurovision-song contest in the phone voting.

7 The Moldovan Diaspora and Moldovan ethno-cultural associations are not synonymous, even though come close. A Diaspora is a group of people, who identify themselves, and keep contact, with their historical motherland, or the country they came from. Ethno-cultural associations are the institutional component of a Diaspora. 
Non-state actors play an important role in cooperation with the Diaspora, mainly it refers to non-governmental organizations, connected with the Diaspora, the Moldovan communities abroad.

The church is quite active in co-operation with the Moldovan communities abroad. Within many European countries (Russia, Italy, France, Portugal, and Spain) Moldovan Orthodox church priests, especially those who are sent to serve abroad, conduct church services in the native language of the Moldovan migrants ${ }^{8}$. Moreover, the Moldovan Metropolitan Church of Russian Orthodox ${ }^{9}$ Church promotes creation of ethnic, cultural and religious communities and associations of Moldovans abroad.

The certain role in strengthening relations with Moldovan communities is played by Trade Unions. Their effectiveness in the protection of migrant workers is low, as they are not too much involved in the implementation of policies to regulate labour migration. The reason falls under the fact that they cannot find their place in the process of protection Moldovan labour migrants abroad. Recently, there have been some positive changes. The Confederation of Independent Trade Unions of Moldova signed a cooperation agreement with the trade Unions in Italy (17.05.2013). The Document provides protection of Moldovans citizens, employed in this country. Since this international document signing, a Moldovan citizen, resident in Italy, would be able to apply to the union, where can be assisted as well as offered legal and social consultations. Then, of course, the person must join the union (Trade, 2013). The Union Trade "Sindicon" signed a cooperation agreement with the Russian Trade Union on this profile. In this context, there is certain positive development in the protection of Moldovan migrants, who work in the field of construction in Russia. However, there is another reason that minimizes the role and influence of trade unions in the protection of Moldovan labour migrants abroad. This is due to the Moldovan policy on labour migration.

It also refers to the feature of Moldovan politics in the field of labour migration. According to the Law on "Labor Migration" (2008) the social

\footnotetext{
${ }^{8}$ The Moldovan citizens' mother-tongue may be different from one person to another; it is due to a combined ethnic composition of the population. It could be Moldovan (Romanian), Russian, Ukrainian, Bulgarian, etc., therefore, to classify it as Moldovan language only would be incorrect. There are people - up to 30 percent of Moldova's citizens - who do not speak Moldovan (Romanian), speak Russian.

${ }^{9}$ Most of Moldova's population (around 98\%) are Christian, who are Orthodox (Moldovan Metropolitan of the Russian Orthodox Church - the majority; the Bessarabia Metropolitan of the Romanian Orthodox Church; the Russian Old Believers (Old Rite) Church), Protestants (Baptists; Jehovah's Witnesses; $7^{\text {th }}$ Day Adventists; etc.); Catholicism (Roman-Catholics and Greek-Catholics).
} 
partners (trade unions and patronage) are not allowed to deal with labor migration. To this end, the international pilot project "Reliable migration ways for migrant workers" (funded by the European Commission - MIGR/2007/130367 (34), where Italian, Ukrainian and Moldovan Trade Unions participated, ended without any result.

\section{Providing civil and political rights}

In the Republic of Moldova dual Citizenship is allowed. The Adoption of dual Citizenship is the result of soft influence of the European Union (Ciumas, 2012).

Moldovan citizens, who live abroad (emigrants), are endowed with the same voting rights as citizens residing in the Republic of Moldova, but with certain exceptions. In the parliamentary elections, emigrants vote and can be elected on equal terms with other citizens. Concerning the elections at the local level, only citizens residing in the Republic of Moldova can vote. At the same time, there is no obstacle if the emigrant tends to run for mayor or municipal councilor. There is not provided any temporary residency requirements to limit the voting rights of a citizen of the Republic of Moldova.

Moldovan citizens can vote individually. The opportunity to vote by post or by proxy is not allowed. In order to vote there is needed to present the passport of the citizen of the Republic of Moldova or the sailor's book. Persons, listed in the consular register, are included in the basic of electoral lists, where at the same time every Moldovan citizen, appearing at a polling station, that lives outside of the Republic of Moldova and is not included in the main list, then he/she is entered in a supplementary list.

The possibility to vote abroad is available only for the parliamentary elections and national referendums. Polling stations are necessarily opened in the diplomatic missions of Moldova (the Election Code). In addition to polling stations in the diplomatic missions, with the consent of the competent authorities of the country, there are also formed polling stations in other locations. The formation of these polling stations is established by the Central Election Commission, on the proposal of the Government, in collaboration with the Ministry of Foreign Affairs and European Integration and other central public administration authorities on the basis of the pre-registration of citizens residing abroad. The immigrants vote in the special (the capital) constituency of the country.

According to the Law on "Citizenship of the Republic of Moldova" (2000), the child is considered to be a citizen of the Republic of Moldova, if he/she at the time of birth has two parents or one of them who is Moldovan. According to the Law on Citizenship of the Republic of Moldova, the multiplicity of citizenship is allowed. Citizens of the Republic of Moldova, having the 
citizenship of another country, in relation with the Republic of Moldova, act only as its citizens, except as required by law.

The law on "The Regime of Foreigners in the Republic of Moldova" (2010) establishes more favorable environment for foreigners. The right of temporary residence may be granted or extended to foreigners, with the right to acquire citizenship of the Republic of Moldova as a result of the recognition or restoration of the citizenship. Under the law it is given the right to the repatriation of persons residing abroad, who were born in Moldova and for some reason did not acquire citizenship of the Republic of Moldova. The same right is also granted to their descendants, regardless where they live.

According to the Constitution of the Republic of Moldova (1994), the law on "Military Duty" fixes the military obligation for young people (men) aged 19 years old. Military service is performed within 1 year. On a contract basis the military duty can be also performed by women at the age of 18 years old. There does not exist any bilateral international agreements on military duty in the Republic of Moldova.

Political parties pay particular attention to migration processes. This applies to the approval of problems, characteristics of causes and trends, but not to the migration policies. In respect of Moldovan emigrant's political parties have certain interests related to electoral support and party membership, participation in investment projects in the Republic of Moldova, the transfer of democratic values and skills in the country of origin. However, these goals are not reflected in the programs of political parties, even parliamentary ones, as the most powerful and effective forces (Makaryan, 2013; Oprunenco, 2012).

The Parliament of the Republic of Moldova, the Central Election Commission of the Republic of Moldova, the Government of the Republic of Moldova, Ministry of Foreign Affairs and European Integration (with CEC) in the field of voting abroad, the Ministry of Information and Development (with CEC) in the area of citizens and updating the voter lists develops policies for electoral process.

\section{Socio-economic rights of emigrants}

Private employment agencies work force provide services before leaving. In Moldova, there are at least 90 private employment agencies. Private employment agencies seek to provide intermediary services (recruitment, selection, and training). The role of agencies on employing the migrant workers is very modest, due to the lack of people's faith in that kind of services, and lack of awareness about their activities, weakness in attracting professional employers, problems with law, etc. (Vaculovschi, 2013). 
In the Republic of Moldova, are signed bilateral and multilateral agreements on avoidance the double taxation and the transfer of social rights. Thus bilateral agreements on avoidance of double taxation were signed, they were ratified and entered into force with 46 countries (24 EU countries); with two countries (Belgium, France) agreements were ratified but they have not entered into the force yet. The activities of the Customs Service of the Republic of Moldova are based on the developed national legislative and regulatory frameworks, international instruments, and bilateral agreements with 10 countries of the EU. However, we cannot say that this is aimed at supporting migrants or the Diaspora.

In Moldova, there is a law on special economic zones. The country has several economic zones, the activity of which is determined by the relevant laws and regulations. The Investment Services are determined by the legislation of Moldova. At the same time, there are no privileges for the Moldovan labour migrants, emigrants or re-emigrants (immigrants) who return to their homeland. There does not exist any special taxation or exemptions for Moldovan citizens, migrant workers or immigrants living abroad.

There exist promotion of remittances in the terms of safety. To this end, we note the information campaigns on the part of international institutions of Moldovan banks to promote the fast money transfer systems, payment cards for migrant workers and their families. The diversification of services based on the fast (electronic) transfers, the emergence of new players in this field led to decrease of fees for the money transfers (Orosco, 2007; Stratan, 2013). There does not exist any special financial products addressed to emigrants in the Republic of Moldova. The rights to property for migrant workers, citizens of the Republic of Moldova residing abroad remain the same as for the Moldovan citizens living in the Republic of Moldova.

Regarding the transfer of social rights of the Republic of Moldova was signed in the agreement on social protection of Moldovan citizens, migrant workers with 10 EU countries (Austria, Luxembourg, Romania, Portugal, the Czech Republic, Estonia, Greece, Belgium, Bulgaria, and Italy) in 2009 2012. The provision of medical services abroad from the side of Republic of Moldova is executed under the possession of the legal status in the country and the individual contracts, in which the issues are specified, these services are also provided from the part of the Moldovan private agencies (Vaculovschi, 2013).

The Bureau on Relation with Diaspora, Ministry of Finance, Ministry of Economy, and Chamber of Licensing are responsible for the development and implementation of the policy in the field of socio-economic rights of migrants. 


\section{Cultural rights of emigrants}

In all pre-university educational institutions of the Republic of Moldova, especially in the areas where Gagauzian and Bulgarian population live, it is compulsory to learn Moldovan, Russian, Gagauzian and Bulgarian languages, and foreign languages (French, English, Spanish, German, Italian, Turkish, Hebrew).

In Moldova there is QSI international school from 1996. In the self-proclaimed and internationally unrecognized Transnistrian region of the Republic of Moldova, the learning process is conducted under own programs, that have not been certified by the Ministry of Education of the Republic of Moldova and similar study programs of the Russian Federation.

Abroad, there are no national schools on studying the national curriculum of the Republic of Moldova. Today there are no schools/associations abroad, where is the national Moldovan language for the labor migrants taught. In 2002 - 2009 in Russia, at the Moscow school number 164 (1164), functioned the Moldavian cultural and educational center, where was possible the optional study of the Moldovan language, history, geography (Poletaev, 2011: 16).

At all pre-university educational institutions of the Republic of Moldova, especially in the areas where Gagauzian and Bulgarian population live, it is compulsory to learn Moldovan, Russian, Gagauzian and Bulgarian languages, and foreign languages (French, English, Spanish, German, Italian, Turkish, or Hebrew).

Until 01.01.2013 the national TV channel Radio Moldova International, and TV Moldova International were broadcasted via satellite. Recently they stopped broadcasting, because of financial reasons (the cost of the satellite services is 3 million per year). Meanwhile was established the web-site of the Company "Teleradio-Moldova", which presents the information in 3 languages (Romanian, Russian, and English), also for the Moldovan Diaspora abroad. The Moldovan non-governmental associations are carrying out online sociological survey with Moldovan emigrants on the resumption of international broadcasting. According to e-voting on the site "noi.md" held until July 30, 2013, votes conducted $59.01 \%$ of the surveyed Moldovan labor migrants abroad: $15.53 \%$ voted "for" the resumption, $3.73 \%$ voted "against", $21.74 \%$ "do not know" are indifferent.

Cultural diplomacy strategy is implemented through the activities of three government agencies: the Bureau for Relations with Diaspora develops a strategy on the concept of cultural diplomacy. It is realized through the Moldovan diplomatic and consular missions - Ministry of Foreign Affairs and European Integration and Interethnic Relations Bureau (promote preservation of ethno-cultural and linguistic identity through funding the national symbols, national costumes and so on). The network of consular institutions of Moldova 
abroad expands in order to protect the Moldovan citizens, especially in the countries with the migrant workers. These days Moldova has 27 embassies, 25 consulates and 3 general consulates abroad.

The Government of the Republic of Moldova, Ministry of Education, Bureau of Interethnic Relations, Bureau on Relations with Diaspora, Ministry of Foreign Affairs and European Integration, Ministry of Culture, State Company "Teleradio-Moldova" are responsible for the development and implementation of these policies.

\section{Conclusions}

Summing up the review of the policies in the field of emigration and Diaspora we note, that the work is carried out at the national level. At the local level the similar policy is implemented at the stage of elaboration, and finding real mechanisms.

In many ways, the current policy of emigration and Diaspora is seen as the result of exposure and cooperation with the international organizations. Government agencies are the main and the most active actors actively using financial and advisory assistance from international actors, influencing development and implementation of the Moldova's migration policy. Now, is important the growing role of non-governmental organizations and associations of Moldovan Diaspora, however their behavior mostly depends on financial possibilities.

At the same time, the ongoing process of competences redistribution, under the context of establishment of the Bureau on Relations with Diaspora, leads us to rethink and deepen the activities related to Diaspora. However, it can also contribute to the appearance of the conflict of interest among the government agencies in the implementation of the migration.

\section{REFERENCES}

The Constitution of the Republic of Moldova, 29.07.1994. // Monitorul Oficial 1, 18.08.1994, http://lex.justice.md/viewdoc.php?action=view\&view=doc\&id=311496\&lang=2;

Law №1245/18.07.2002 on preparing the Citizens for their Country Defence. // Monitorul Oficial 137-138, 10.10.2002, http://lex.justice.md/md/312749/

Presidential Decree Nr.1638-II / 30.08.2000 on support persons from Moldova residing abroad and work with them. // Monitorul Oficial nr.1115, 05.09.2000, http://www.ambasadamoldova.cz/doc/diaspora/Decret_2000-md.pdf

Pilot Program for Attracting Remittances in Economics "PARE $1+1$ " for 2010-2012 (approved by the Decision of the Government nr.972, 18.10.2010).// Monitorul Oficial nr.108-109/611, 29.06.2010

http://lex.justice.md/viewdoc.php?action=view\&view=doc\&id=336486\&lang=1 
The Decision of the Government №655/08 September 2011 on the National Strategy on Migration and Asylum (2011-2020). // Monitorul Oficial nr.152-155/726, 16.09. 2011

http://lex.justice.md/viewdoc.php?action=view\&view=doc\&id=340066\&lang=1

The Decision of the Government №657/06.11.2009 for approving the Regulation on organization, functioning, structuring the limit-effectiveness of the State Chancellery. // Monitorul Oficial 162, 10.11.2009,

http://lex.justice.md/viewdoc.php?action=view\&view=doc\&id=332599\&lang=1

Activity report of the Bureau for Relations with Diaspora of the State Chancellery of the Government of the Republic of Moldova "A year of creation". - Chisinau, BRD, 2013, 32 p. (Romanian)

Brunarska Z., Mananashvili S., Weinar A. (2013) Return, readmission and reintegration in the Eastern Partnership countries: An overview. // CARIM-East RR 2013/17, Migration Policy Centre, European University Institute, 24 p., http://www.carim-east.eu/media/CARIM-East-RR-2013-17.pdf

Ganta V. (2012) The demographic and economic framework of circular migration in Moldova. // CARIM-East Explanatory Note 12/69, September, 2012, Migration Policy Centre, European University Institute, 6 p., http://www.carimeast.eu/media/exno/Explanatory\%20Notes_2012-69.pdf

Cabacenco P. (2006) On the Moldovan Diaspora: promoting transnational migrant networks via the Internet. // Population of the Republic of Moldova in the context of international migration. Vol.I. - Iaşi: Pan-Europe, p.96-103 (Russian)

Cheianu-Andrei D. (2013) Mapping of the Moldovan Diaspora in Italy, Portugal, France and the United Kingdom. - Chisinau, IOM, 140 p.

Ciumas T. (2012) The Legal Framework for Circular Migration in Moldova. // CARIM-East Explanatory Note 12/74, September 2012, Migration Policy Centre, European University Institute, $9 \mathrm{p}$. http://www.carim-east.eu/media/exno/Explanatory\%20Notes_2012-74.pdf

Makaryan S. (2013) Migration Rhetoric in Political Party Programs: Comparative Review of Case-Studies of Armenia, Azerbaijan, Belarus, Georgia, Moldova, Russia and Ukraine. CARIM-East Research Report 2013/28, 18 p., http://www.carim-east.eu/media/CARIM-East-RR-2013-28.pdf

Moldova after the global crisis: promoting competitiveness and shred growth (2011). April 4, 2011. World Bank, 207 p.

Moraru V., Mosneaga V., Rusnac G. (2012) Migration pendulum. - Chisinau, "Tipografia-Sirius", 200 p. (Russian)

Morozan A., Margarint A. (2006) The formation of the Moldovan Diaspora in relation to labor migration: present and perspectives. // MOLDOSCOPIE (Probleme de analiză politică). - Chişinău: USM, nr.4 (XXXV), p.29-42 (Romanian)

Mosneaga V. (2013) The formation of the Moldovan Diaspora and Migration Policy of the Republic of Moldova. // MOLDOSCOPIE (Probleme de analiza politica). $-\mathrm{nr} .3$ (LXIII), 2013. - Chisinau: CEP USM, 2013, p.18-34 (Russian)

Mosneaga V. (2012a) Moldova: Emigration And Diaspora. // CARIM-East Explanatory Note 12/110, September 2012, Migration Policy Centre, European University 
Institute, 8 p., http://www.carim-east.eu/media/exno/Explanatory\%20Notes_2012110.pdf

Mosneaga V. (2012b) Moldovan Labour Migrants in the European Union: Problems of Integration. CARIM-East Research Report 2012/41, Migration Policy Centre, European University Institute, 20 p., http://www.carim-east.eu/media/CARIM-East2012-RR-41.pdf

Mosneaga V. (2012c) Circular Migration of the Population of the Republic of Moldova. // CARIM-East Explanatory Note 12/68, September 2012. Migration Policy Centre, European University Institute, 9 p., http://www.carimeast.eu/media/exno/Explanatory\%20Notes_2012-68.pdf

Mosneaga V., Moraru V., Rusnac Gh., Turcan V. (2011) Bonding process: labor migration from Moldova to Italy. - Chisinau, Editerra-Prim, 263 p. (Romanian)

Mosneaga V., Rusu R. (2008) The formation of the Moldovan Diaspora abroad: the essence and specificity. // MOLDOSCOPIE (Probleme de analiza politica). nr.1 (XL). - Chisinau: CEP USM, p.91-104 (Romanian)

Mukomel V., Cheianu-Andrei D. (2013) Moldovans in the Russian Federation: SocioEconomic Profile and Policy Challenges. - Chisinau, IOM, 112 p.

Oprunenco A. (2012) Migration Issue in Programs and Platforms of Political Parties in Moldova. CARIM-East Explanatory Note 11/21. Socio-political Module. January 2012, 5 p.,

http://www.carim-east.eu/media/sociopol_module/Explanatory\%20Notes\%20Mol dova\%2021.pdf;

Orozco M. (2007) Looking forward and Including Migration in Development: Remittance Leveraging Opportunities for Moldova. September 2007. - Chisinau, IOM, 136 p., http://www.iom.md/materials/4_looking_forward_eng.pdf;

Poletaev D.V. (2011) Research on Moldova Diaspora Involvement in Protection of Rights of Migrants' Children in the Republic of Moldova. - Moscow, Terre des hommes, $57 \mathrm{p}$.

Stratan A., Chistruga M., Clipa V., Fala A., Septelici V. (2013) Development and side effects of remittances in the CIS countries: the case of Republic of Moldova. // CARIM-East RR 2013/25, Migration Policy Centre, European University Institute, 56 p, http://www.carim-east.eu/media/CARIM-East-RR-2013-25.pdf

Trade unions of Moldova will protect the rights of Moldovan migrants in Italy, http://www.kp.md/daily/26078/2983494/ (Russian)

Schwartz R. (2007) Exploring the Link between Moldovan Communities abroad (MCA) and Moldova. May 2007. - Chisinau, IOM, 43 p. http://www.iom.md/materials/9_diaspora_and_ocv_final_report_eng.pdf

Vaculovschi D., Lipcanu O., Popova N., Panzica F. (2013) Private employment agencies in the Republic of Moldova. - Chisinau: ILO, $30 \mathrm{p}$.

Victor Lutenco: About program for children of Diaspora "Dor". // http://www.allmoldova.com/int/interview/victor-lutenco-050713.html (Romanian)

Vremis M., Craievschi-Toarta V., Burdenii E., Herm A., Poulen M. (2013) Extended migration profile of the Republic of Moldova. - Chisinau, IOM, $312 \mathrm{p}$. 
Valeriu Mosneaga is the Professor of Political Science, the Institute of Social Sciences, University of Cyril and Methodius in Trnava, Slovakia. His research interests are in the field of International and Moldovan migration, formation and activities of the multi-party system, European integration of the post-soviet countries. He has worked on many research and policy projects in the field of migration.

He is the author of fifteen books and and more than 400 publications in book chapters, scientific journals and conference proceedings. His recent publications: Mosneaga, V., Gh. Rusnac, V. Turcan (2013) Moldova in the context of Migrations. Bibliography (1990 - 2012). Chisinau. Mosneaga, V., E. Burdelinii, L. Vasilieva, O. Malinowskaia (2012) The problems of reintegration and return of labor migrants from EU to' countries of "Eastern Neighborhood". Vilnius. Moraru, V., V. Mosneaga, G. Rusnac (2012) The pendulum of migration. Chisinau. Mosneaga, V., V. Moraru, V. Turcan, G. Rusnac (2011) Facets of a process: Moldovan labor migration from Moldova to Italy. Chisinau.

\author{
Valeriu Mosneaga \\ Department of Political Science \\ Institute of Social Sciences \\ University of Cyril and Methodius in Trnava \\ Slovakia \\ E-mail: mosneaga@hotmail.com
}

